\title{
EFFECTS OF WATER REPLACEMENT FREQUENCY ON THE GROWTH AND SURVIVAL OF HETEROBRANCHUS LONGIFILIS VALENCIENNNES, 1840) FINGERLINGS REARED IN CONCRETE TANKS
}

\author{
R.C.A Orji and K.E. Esabi \\ Department of Fisheries and Aquatic Resources \\ Management, Michael Okpara University of \\ Agriculture Umudike, Abia State, Nigeria
}

\begin{abstract}
The effect of water replacement frequency on growth and survival of fingerlings (4.21 \pm 0.39 mean weight) of African catfish Heterobranchus longifilis was investigated in concrete tanks of dimension $2 \mathrm{~m} \times 2 \mathrm{~m} \times 1 \mathrm{~m}\left(4 \mathrm{~m}^{2}\right)$ over a period of sixty days. There were five treatments namely: Treatment $A=$ daily water replacement; Treatment $B=$ replacement every two day; Treatment $C=$ replacement every three days; Treatment $D=$ replacement every six day; Treatment $E=$ no water replacement (control). The fish were fed with well balanced artificial diet at 3\% body weight daily at $0800 \mathrm{hrs}$ and $1700 \mathrm{hrs}$. The results show that fingerlings in treatment $D$ had the best specific growth percentage of 5.32\% and feed conversion ratio of 1:3.35 while treatment $E$ was poorest with specific growth percentage of 1.33\% and feed conversion ratio of 1: 9.20.Treatment A had 100\% survival while treatment $E$ had the least survival rate of $30 \%$. Generally it was observed that the lesser the frequency of water replacement the better the growth performance while the reverse was the case with survival rate of the fish fingerlings. It is recommended that an every six day and upward of water replacement frequency be adopted to avoid the problem associated with stress.
\end{abstract}

\section{INTRODUCTION}

The provision of requisite feeds and maintenance of an ideal aquatic environment are obviously necessities for health and good growth of fish in ponds or any kind of culture system. Fish eat most of the feed supplied to the ponds but on dry matter basis, only $25 \%$ of the nutrients in the feed are converted to fish flesh, (Boyd 1982). The rest of the nutrient enters the water as metabolic wastes. These wastes include Carbon (IV) oxide, ammonia, phosphate and other inorganic and organic substances which are colloidal. These can be hazardous to the fish health (Kim 1983). As more materials continue to accumulate in the bottom of the pond, available oxygen is depleted.

A lot of work has been done on growth response of fish fingerlings reared in tanks; (Odo and Inyang, 2001; Absalom et al, 1999; Orji and Agunwa, 2006).Boyd and Litchtoppler (1979) noted that fish production increases linearly with feeding rate while water quality deteriorates exponentially with feeding rates most especially when majority of aquatic organisms need oxygen and must obtain it from the surrounding water. Absalom and Omenaihe (2000) noted that the lesser the frequency of water replacement, the better the growth performance and survival rate of fish fry. In intensive culture therefore, a key factor in determining the carrying capacity is the relationship between oxygen consumption and the quality of food supplied. 
In the absence of a water recirculation system, water management for rearing fish fry and fingerlings in hatcheries involves daily change of a portion of or all the water. This study was carried out to determine the effects of frequency of water replacement on the growth and survival of Heterobranches longifilis fingerlings and its implication in water quality management under tropical condition.

\section{MATERIALS AND METHODS}

Experimental Layout: The experimental set up consisted of five treatments as follows Treatment $\mathrm{A}=$ daily water replacement. Treatment $\mathrm{B}=$ replacement every two days Treatment $\mathrm{C}=$ replacement every three days. Treatment $\mathrm{D}=$ replacement every six days Treatment $\mathrm{E}=$ no water replacement which served as the control. Each of the treatments was replicated thrice. The experimental tanks $-2 \mathrm{~m} \times 2 \mathrm{~m} \times 1 \mathrm{~m}$ (or $4 \mathrm{~m}^{2)}$ were covered with nylon mesh nets to prevent fish escape and entry of undesirable substances. Removal of water from each treatment tank was carried out by siphoning with reinforced hose of $1.5 \mathrm{~cm}$ diameter. Sampling of fish was done bi-weekly. The investigation lasted for sixty days.

Water Quality Measurement: Water quality parameters (temperature, $\mathrm{P}^{\mathrm{H}}$, free Carbon dioxide, and dissolved oxygen) were monitored in the experimental tanks according to methods described in APHA (1985).Temperature was determined with mercury in glass thermometer, immersed in water and allowed to stand for two minutes, for equilibration before taking the reading. For the $\mathrm{P}^{\mathrm{H}}$, the electrode of the $\mathrm{P}^{\mathrm{H}}$ meter was lowered into the water and the value read from the digital display screen. Free Carbon dioxide was determined by the titrimetric method using phenolphthalein indicator. Winkler titration method was used to determine the dissolved oxygen (DO).

Feeding Of Fish: The fish were fed with artificial feed throughout the investigation period. Fish were fed $3 \%$ of their body weight, two times daily at 0800 hours and 1700 hours. Proximate analysis of feed was by the method of Association of Official Analytical Chemists (A.O.A.C) (1980).

Growth Measurement: Food efficiency was calculated biweekly. Length and weight measurements were determined with measurement board and triple beam balance respectively. From results obtained, the specific growth percentage and food efficiency were determined, using Weatherly and Rogers (1978) formulae as follows:

Growth rate $(\mathrm{gm} /$ day $)=\quad$ Weight gain $(\mathrm{gm})$ Culture period (days)

Specific Growth Rate (\% body weight/day)

$=\quad($ Final weight - Initial weight $) \times 100$ 
Apparent feed conversion Ratio $=\underline{\text { feed intake }}$

\section{Weight gain}

The data collected were subjected to analysis of variance (ANOVA) of completely randomized experiment.

Model $=\mathrm{CRD}(\mathrm{xij})=\mathrm{M}+\mathrm{Ti}+\mathrm{Eij} \quad($ Green,1977)

Where $\mathrm{M}=$ unknown population variance

$\mathrm{Ti}=$ mean treatment effect

Eij= experimental error term

\section{RESULTS}

Results of growth indices, survival rate and feed conversion ratio of the fingerlings are presented in Table 1. The results show that fingerlings in treatment $\mathrm{D}$ (water replacement every 6 days) had the best percentage weight gain of $75.59 \%$ ( 3.19grams), followed by treatment $\mathrm{C}$ $68.43 \%(2.89 \mathrm{~g})$, and B 63.74\% (2.69) respectively. Treatments A (31.50\%) and E (31.50\%) were significantly lower $(\mathrm{P}>0.05)$ than those of $\mathrm{D}, \mathrm{C}$ and $\mathrm{B}$. The same trend was observed in the specific growth rates. However, treatment A had 100\% survival rate followed by $\mathrm{B}, \mathrm{C}$ and $\mathrm{D}$ with $90 \%$ survival rate each while treatment $\mathrm{E}$ had the least survival rate of $30 \%$.Treatment $\mathrm{D}$ had the best feed conversion ratio followed by C,B,A and lastly E.

TABLE 1: Growth indices, survival rate and feed conversion ratio of Hererobranchus Longifilis fingerlings treated with 5 different water replacement frequencies

\begin{tabular}{|c|c|c|c|c|c|c|c|}
\hline $\begin{array}{l}\text { Treatm } \\
\text { Initial }\end{array}$ & $\begin{array}{l}\text { ent Mean } \\
\text { Final Gain } \\
\text { Weight } \\
\text { (g) }\end{array}$ & $\begin{array}{l}\text { Mean } \\
\text { (\%) } \\
\text { Weight }\end{array}$ & $\begin{array}{r}\text { Weight } \\
(\%)\end{array}$ & day $^{-1}$ & $\begin{array}{l}\text { Survival } \\
(\%)\end{array}$ & Feed & Conversion \\
\hline A & $4.22 \pm 0.33$ & 5.55 & \pm 0.62 & $31.50 \%$ & 2.22 & 100 & $1: 6.72$ \\
\hline B & $4.22 \pm 0.58$ & 6.01 & \pm 0.47 & $63.74 \%$ & 4.52 & 90 & $1: 3.71$ \\
\hline $\mathrm{C}$ & $4.22 \pm 0.12$ & 7.11 & \pm 0.47 & $68.43 \%$ & 4.82 & 90 & $1: 3.52$ \\
\hline D & $4.22 \pm 0.41$ & 7.31 & \pm 0.65 & $75.59 \%$ & 5.32 & 90 & $1: 3.35$ \\
\hline $\mathrm{E}$ & $4.21 \pm 0.39$ & 5.01 & \pm 0.03 & $31.50 \%$ & 1.33 & 30 & $1: 9.20$ \\
\hline
\end{tabular}

\section{Water Quality Parameters}

The initial water quality parameters prior to commencement of investigation and stocking (Table 2) fell within the range suitable for fish culture as recommended by Boyd and Lichthoppler (1979). The values remained fairly constant especially temperature and $\mathrm{P}^{\mathrm{H}}$. Slight variations were observed in free Carbon dioxide and dissolved oxygen. For example treatment E had $4.90 \mathrm{mg} / 1$ of free carbon-dioxide while A was $0.6 \mathrm{mg} / 1$. Also the value for dissolved oxygen was $4.7 \mathrm{mg} / \mathrm{l}$ for treatment $\mathrm{E}$ while A was $7.60 \mathrm{mg} / \mathrm{l}$. proximate analysis of the experimental diet is presented in Table 3 . 
Table 2: Values of water quality parameters during the experimental period.

\section{WATER ANALYSIS AT SOURCE}

\begin{tabular}{|c|c|c|c|c|c|c|}
\hline A & B & $\mathrm{C}$ & $\mathrm{D}$ & E & & \\
\hline Temperature $\left({ }^{0} \mathrm{C}\right)$ & $27^{\circ} \mathrm{C}$ & $25^{\circ} \mathrm{C}$ & $25^{\circ} \mathrm{C}$ & $25^{\circ} \mathrm{C}$ & $25^{\circ} \mathrm{C}$ & $25^{\circ} \mathrm{C}$ \\
\hline PH & 7.08 & 7.07 & 7.04 & 7.16 & 7.19 & 7.09 \\
\hline Dissolved Oxygen $(\mathrm{Mg} / \mathrm{l})$ & 9.30 & 7.60 & 6.60 & 6.10 & 5.10 & 4.75 \\
\hline Free Carbon (IV) Oxide (mg/l) 0.6 & 0.7 & 0.85 & 0.88 & 1.30 & 4.90 & \\
\hline
\end{tabular}

TABLE 3: Proximate composition of the artificially formulated Feed (\% dry weight). SOURCE, ARAC (P. H)

\section{INGREDIENTS}

Fish Meal

Wheat bran

Blood Meal

Groundnut cake

Premix

\section{MEAN VALUES OF TREATMENTS}

\section{PROXIMATE ANALYSIS OF FEED}

Crude protein

Crude Fiber

Lipid Content

Ash Content

Moisture

\section{COMPOSITION (\%)}

$25 \%$

$20 \%$

$3.5 \%$

$8 \%$

$1 \%$

TABLE 4: Mean water quality parameters for $\boldsymbol{H}$. longifilis fingerling treated with various changes

\begin{tabular}{llll} 
Sample & PH & Oxy & CARBONDIOXIDE \\
A & $7.075 \pm 0.05^{\mathrm{d}}$ & $7.61 \pm 0.01^{\mathrm{a}}$ & $0.72 \pm 0.01^{\mathrm{e}}$ \\
B & $7.045 \pm 0.05^{\mathrm{e}}$ & $6.61 \pm 0.01^{\mathrm{b}}$ & $0.85 \pm 0.00^{\mathrm{d}}$ \\
C & $7.165 \pm 0.05^{\mathrm{b}}$ & $6.1 \pm 0.00^{\mathrm{c}}$ & $0.88 \pm 0.01^{\mathrm{c}}$ \\
D & $7.19 \pm 0.00^{\mathrm{a}}$ & $5.055 \pm 0.01^{\mathrm{d}}$ & $1.30 \pm 0.00^{\mathrm{b}}$ \\
E & $7.091 \pm 0.01^{\mathrm{c}}$ & $4.75 \pm 0.00^{\mathrm{e}}$ & $4.90 \pm 0.00^{\mathrm{a}}$ \\
\hline
\end{tabular}

Means followed by the same letter are not significantly different $(P>0.05)$ 


\section{DISCUSSION}

Percentage weight gains and specific growth rates were observed to increase with decreasing frequency of water replacement. The highest specific growth rate of $5.32 \%$ was recorded in treatment $\mathrm{D}$ of every six days water replacement due to less stress imposed to the fish while the least was recorded by $\mathrm{E}$ with a value of $1.33 \%$ of no water replacement possibly due to stress arising from high free Carbon dioxide accumulation in water

Fish were fed with well balanced diet of $35 \%$ crude protein, $6.78 \%$ crude fiber $4.75 \%$ lipid content, $7.35 \%$ ash and $8.82 \%$ moisture. Since these values fall within the acceptable range (Halver 1972), for good fish fingerling growth, the mortality of fish and difference in growth response could not have been as a result of inadequacies of the diet. It is probable that the cause of mortality recorded was due to the depleted oxygen content from $9.30 \mathrm{mg} / 1$ from source at onset of the study to a low level of $4.75 \mathrm{mg} / 1$ in treatment $\mathrm{E}$ in particular. Mortality and differences in growth must have been as a result of handling stress necessitated by water replacement in different treatments.

During the culture period, accumulation of faecal matter and decomposition of excess food possibly played a significant role in depletion of dissolved oxygen and high level of free carbon dioxide build up. However, the differences in the values of dissolved oxygen and free Carbon dioxide were slight. The mean dissolved oxygen was observed to be highest in treatment A with a value of $7.60 \mathrm{mg} / 1$ and lowest in treatment $\mathrm{E}$ of $4.75 \mathrm{mg} / \mathrm{l}$. This is due to the high frequency of water replacement in treatment $\mathrm{A}$ and low frequency of treatment $\mathrm{E}$.

The free carbon (IV) oxide content was observed to be lowest in treatment A and highest in treatment $E$ with values of $0.70 \mathrm{mg} / 1$ and $4.90 \mathrm{mg} / 1$ respectively due to the same reason above. In natural environment as in many static culture systems, allowing water to stand for long would aid the production of natural food. Marietta (1990) noted that daily water replacement is not necessary but every other daily management scheme is good in rearing larvae of milk fishChanos chanos. The implication therefore is that in static water culture systems, water should be replaced, but not too frequent as this can lead to stress and eventually death of fish. For best results in the management of $\mathrm{H}$. longifilis fingerlings, it is recommended that water replacement frequency of 6- day intervals or longer should be adopted.

\section{REFERENCES}

Absalom, K.V.and Omenaihe, O. (2000). Effect of water replacement rate on growth and survival of the Nile Tilapia fry. Journal of Aquatic Sciences, vol. 15:19-22.

Absalom, K.V., Omorege, E., and Igbe, A.M.(1999).Effect of kidney bean meal on growth performance of Nile Tilapia. Journal of Aquatic Sciences, vol. :55-60. 
AOAC (1980) (Association of Official Analytical Chemists). Official methods of analysis of the AOAC. Hortwitz, W. (Ed.) $12^{\text {th }}$ Ed. AOAC Washington DC pp $12-858$.

APHA (American Public Health Association 1985). Standard methods for Water and waste water, New York, APHA, AWWA, WPCF Washington DC, $15^{\text {th }}$ Edition 1076 pp.

Boyd, C.E. (1982). Nutritive quality of food in ecological systems Archiv for Hydrobiology 69: $256-270$.

Boyd, C.E. and Lichthoppler, F. (1979). Water quality management in pond fish culture. Res. and Dev. Ser. No. 222 project AID/DSAN 00039 Auburn University Alabalma USA.

Green, R.H.(1979). Sampling design and statistical methods for environmental biologists, John Willy and sons, New York,257 pp.

Halver, J.E. (1972). Fish nutrition, Academic press, New York and London 7.3pp.

Kim, I.B (1983). Fish nutrition and water quality. Aquaculture Trans course Sept. 1983, Federal Department of Fisheries, Kaduna 30 pp.

Marietta, N.D. (1990). Water management for rearing milkfish larvae. SEAFDEC. Asian aquaculture xii $8-9$.

Odo, G.E. and Inyang, N.M. (2001). Growth, feed utilization and survival of African catfish fingerlings reared in tanks at different salinity levels. Journal of Aquatic Sciences. Vol. 16 (2):124-126.

Orji, R.C.A. and Agunwa, A.C. (2006). Growth response, feed utilization and survival of Heterobranchus longifilis reared in concrete tanks, 2006 Fisheries Society of Nigeria Conference Proceedings (accepted for publication).

Weatherly, A.H and Rogers, S.C. (1978). Some aspects of age and growth. Pages 52 - 74. In S.D. Gerking (ed.). Ecology of fresh water fish Production, Blackwell scientific Publication, Oxford. 